Khazan, V. B. "Akademyk V. Y. Vernadskyi y paradyhma ustoichyvoho razvytyia" [Academician V. I. Vernadskiy and Sustainable Development Paradigm]. Naukovi pratsi [Chornomorskoho derzhavnoho universytetu imeni Petra Mohyly kompleksu «Kyievo-Mohylianska akademiia»]. Seriia «Ekolohiia», vol. 256, no. 244 (2015): 19-23.

Kun, T. Struktura naukovykh revoliutsii [The Structure of Scientific Revolutions]. Kyiv: Port-Royal, 2001.

Marchenko, N. "Zagadochnyy tsikl Deminga, chem on mozhet byt polezen?" [Mysterious Deming Cycle, How
Can It Be Useful?]. https://ipland.com.ua/ru/blog/zagadochnyj-cikl-deminga-chem-mozhet-byt-polezen/

Morshchenok, T. S. "Benchmarkinh yak instrument pidvyshchennia konkurentospromozhnosti pidpryiemnytskykh struktur" [Benchmarking as an Instrument of Increase of Business Structures Competitiveness]. Ekonomika i suspilstvo. 2017. http://www.economyandsociety.in.ua/journal/9_ukr/92.pdf

Sait kompanii «BEIKER TILLI Ukraina». https://bakertilly.ua/ services/консалтингові-послуги/сталий-розвиток

\title{
IMPROVING THE SYSTEM OF INDICATORS FOR ECONOMIC AND STATISTICAL DETERMINATION OF ENTERPRISE EFFICIENCY WITH REGARD TO LEGAL ASPECTS OF MANAGEMENT
}

\author{
${ }^{\circ} 2020$ SKRYNKOVSKYY R. M., ZAIATS 0. S.
}

UDC 65.01

JEL: M21; M59; K19

\section{Skrynkovskyy R. M., Zaiats O. S. Improving the System of Indicators for Economic and Statistical Determination of Enterprise Efficiency with Regard to Legal Aspects of Management}

The object of the research is the peculiarities of the formation, use and improvement of the system of indicators for economic and statistical determination of enterprise efficiency with regard to legal aspects of management. It is determined that the enterprise efficiency is the ability of enterprise to provide the efficiency (effect) of process, project, activities, etc., which can be calculated as the ratio of the effect (achieved result in a certain form of manifestation - monetary, material, social, ecological, etc.) to the costs that ensured this result in the system of determining the result of economic activity «information - resource - time - conditions (risk factor, opportunity) - responsibility.» It is identified that in practice there are problems related to the formation and use of the system of indicators for economic and statistical determination of enterprise efficiency, taking into consideration the legal responsibility of business. It is determined that under the legal responsibility of business should be understood the following: 1) duty of managers to respect the legality of actions in achieving the economic goals of the enterprise; 2) five main groups of legal responsibilities of managers: to the owners (board of directors), to the staff (subordinates), to customers, to suppliers, and to competitors of the enterprise. The results of the research improve the system of indicators for economic and statistical determination of enterprise efficiency, taking into account: financial and economic efficiency; production efficiency; commercial efficiency; legal efficiency - depending on the level of compliance with the legality of the actions of managers in achieving the economic goals of the enterprise in the financial, economic, industrial and commercial spheres. All this should be taken into account when improving the system of integrated diagnostics of the enterprise's competitiveness to form and support the process of making and implementing managerial decisions, including checking up effectiveness of these decisions in the management system.

Keywords: enterprise, enterprise efficiency, legal responsibility of business, managerial decisions, economic goals, profit, effect (result), costs (resources). DOl: $h$ ttps://doi.org/10.32983/2222-4459-2020-3-416-422

Fig.: 1. Formulae: 1. Bibl.: 32.

Skrynkovskyy Ruslan M. - PhD (Economics), Associate Professor, Professor of the Department of Business Economy and Information Technology, Lviv University of Business and Law (99 Kulparkivska Str., Lviv, 79021, Ukraine)

E-mail: uan_lviv@ukr.net

ORCID: $h$ ttp://orcid.org/0000-0002-2180-8055

Zaiats Olha S. - PhD (Law), Associate Professor of the Department of Civil Law Disciplines, Lviv State University of Internal Affairs (26 Horodotska Str., Lviv, 79066, Ukraine)

E-mail: zayats.olga@ukr.net

ORCID: http://orcid.org/0000-0003-2872-5567

УДК 65.01

JEL: M21; M59; K19

Скриньковський Р. М., Заяць О. С. Удосконалення системи показників для економіко-статистичного визначення ефективності діяльності підприємства з урахуванням правових аспектів менеджменту

Об'єктом дослідження є особливості формування, використання та вдосконалення системи показників для економіко-статистичного визначення ефективності діяльності підприємства з урахуванням правових аспектів менеджменту. 3’ясовано, що ефективність діяльності підприємства - це здатність підприємства забезпечувати результативність (ефект) процесу, проєкту, заходів тощо, яку обчислюють як відношення ефекту (досягнутого результату в певній формі вияву - грошовій, матеріальній, соціальній, екологічній тощо) до витрат, що забезпечили цей результат у системі визначення результату економічної діяльності «інформація - ресурс - час - умови (фактор ризику, можливість) - відповідальність». Виявлено, що на практиці існують проблеми, пов'язані з формуванням і використанням системи показників для економіко-статистичного визначення ефективності діяльності підприємства з урахуванням юридичної відповідальності бізнесу. Встановлено, що під юридичною відповідальністю бізнесу слід розуміти: 1) обов'язок менеджерів дотримуватися законності дій при досягненні економічних цілей підприємства; 2) п'ять основних груп юридичних обов'язків менеджерів: перед власниками (радою директорів), перед персоналом (підлеглими), перед клієнтами, перед постачальниками та перед конкурентами підприємства. За результатами дослідження вдосконалено систему показників для економікостатистичного визначення ефективності діяльності підприємства, яка враховує: фінансово-економічну ефективність; виробничу ефектив- 
ність; комерційну ефективність; правову ефективність - залежно від рівня дотримання законності дій менеджерами при досягненні економічних цілей підприємства у фінансово-економічній, виробничій і комериійній сферах. Усе це доцільно враховувати при вдосконаленні системи комплексної діагностики конкурентоспроможності підприємства для формування та підтримки процесу прийняття та реалізації управлінських рішень, включаючи перевірку есрективності цих рішень у системі менедженту.

Ключові слова: підприємство, ефективність діяльності підприємства, юридична відповідальність бізнесу, управлінські рішення, економічні цілі, прибуток, ефект (результат), витрати (ресурси).

Рис.: 1. Формул: 1. Бібл.: 32.

Скриньковський Руслан Миколайович - кандидат економічних наук, доцент, професор кафедри економіки підприємств та інформаційних технологій, Львівський університет бізнесу та права (вул. Кульпарківська, 99, Львів, 79021, Україна)

E-mail:uan_lviv@ukr.net

ORCID: http://orcid.org/0000-0002-2180-8055

Заяць Ольга Степанівна - кандидат юридичних наук, доцент кафедри цивільно-правових дисциплін, Львівський державний університет внутрішніх справ (вул. Городоцька, 26, Львів, 79066, Україна)

E-mail: zayats.olga@ukr.net

ORCID: http://orcid.org/0000-0003-2872-5567

УДК 65.01

JEL: M21; M59; K19

Скрыньковский Р. Н., Заяц О. С. Совершенствование системы показателей для экономико-статистического определения эффективности деятельности предприятия с учетом правовых аспектов менеджента

Объектом исследования являются особенности формирования, использования и совершенствования системы показателей для экономикостатистического определения эффрективности деятельности предприятия с учетом правовых аспектов менеджмента. Установлено, что эффективность деятельности предприятия - это способность предприятия обеспечивать результативность (эффект) процесса, проекта, мероприятий и т. п., которую вычисляют как отношение эффекта (достигнутого результата в определенной форме проявления - денежной, материальной, социальной, экологической и т. д.) к затратам, обеспечившим этот результат в системе определения результата экономической деятельности «информация - ресурс - время - условия (фактор риска, возможность) - ответственность». Выявлено, что на практике существуют проблемы, связанные с формированием и использованием системы показателей для экономико-статистического определения эфрфективности деятельности предприятия с учетом юридической ответственности бизнеса. Установлено, что под юридической ответственностью бизнеса следует понимать: 1) обязанность менеджеров соблюдать законность действий при достижении экономических целей предприятия; 2) пять основных групп юридических обязанностей менеджеров: перед владельцами (советом директоров), перед персоналом (подчиненными), перед клиентами, перед поставщиками и перед конкурентами предприятия. По результатам исследования усовершенствована система показателей для экономико-статистического определения эффективности деятельности предприятия, которая учитывает: финансово-экономическую эффективность; производственную эффективность; коммерческую эффективность; правовую эффрективность в зависимости от уровня соблюдения законности действий менеджерами при достижении экономических целей предприятия в финансовоэкономической, производственной и коммерческой сферах. Всё это челесообразно учитывать при совершенствовании системы комплексной диагностики конкурентоспособности предприятия для формирования и поддержки процесса принятия и реализации управленческих решений, включая проверку эффективности этих решений в системе менеджента.

Ключевые слова: предприятие, эффективность деятельности предприятия, юридическая ответственность бизнеса, управленческие решения, экономические чели, прибыль, эффрект (результат), расходы (ресурсы).

Рис.: 1. Формул: 1. Библ.: 32.

Скрыньковский Руслан Николаевич - кандидат экономических наук, доцент, профессор кафедры экономики предприятий и информационных технологий, Львовский университет бизнеса и права (ул. Кульпарковская, 99, Львов, 79021, Украина)

E-mail:uan_Iviv@ukr.net

ORCID: http://orcid.org/0000-0002-2180-8055

Заяч Ольга Степановна - кандидат юридических наук, дочент кафедры гражданско-правовых дисциплин, Львовский государственный университет внутренних дел (ул. Городоцкая, 26, Львов, 79066, Украина)

E-mail: zayats.olga@ukr.net

ORCID: http://orcid.org/0000-0003-2872-5567

A s practice shows, one of the basic (defining) characteristics of an enterprise's development (from a managerial point of view) in the VUCA world (VUCA is an acronym that comes from the words volatility, uncertainty, complexity and ambiguity) is its development potential $[1 ; 2]$. At the same time, it is known that achievement of success by any enterprise (under conditions of continuous intensification of competition in the market, limited resources, information restrictions, lack of qualified personnel, intensive updating of equipment and technologies, etc.) directly depends on its competitiveness [3-5].

According to academic economists $[3 ; 4 ; 6]$, enterprise competitiveness is a synthetic spatial and temporal parameter that not only takes into account qualitative and cost characteristics of products but also reflects the enterprise's performance efficiency, which together (as a system) allows it to occupy an appropriate position in the market with a certain level of competition intensity.

Based on the analysis of literary sources [7-9] and business practices, it was established that efficiency should be considered as the relationship of the 2 following aspects: 1 ) ability to achieve the goal (expected result); 2) optimal ratio of spent resources (financial, labor, material, and energy [10]) and the result (outcome) obtained in the system "information - resource - time conditions (risk factor, opportunity) - responsibility". 
$\mathrm{H}$ ence, based on the understanding of the essence of the economic category "efficiency" $[3 ; 11 ; 12]$ and taking into account the opinion of top managers of enterprises, it is obvious that the studied indicator (level of enterprise efficiency) is a multi-facet integrated concept, which: includes both financial and nonfinancial business indicators (quantitative and qualitative indicators with corresponding criteria values); characterizes separate (defined) areas, specific operations, various types of enterprise activities (financial, industrial, investment, innovative, marketing, etc.); reflects quality of the management system, including, in particular, legal aspects of management.

Here, in the opinion of top executives (managers), of particular importance are methods of expert evaluation; diagnosis (targeted assessment) of a particular object, phenomenon, or process (based on a system of indicators) [12]; economic and mathematical modeling of a problem.

In [3], it is pointed out that diagnosing an enterprise is not a one-time event but a systematic permanent activity, which involves studying (targeted economic assessment) of its condition and trends, identifying threats and development prospects in order to make informed rational managerial decisions aimed at eliminating problem issues (threats) and weaknesses of the enterprise or taking advantages of the operating conditions (opportunities) and strengths of the enterprise for ensuring a qualitatively new level of its efficiency, development and forming prospects [3, 12-14]. At the same time, in the course of scientific research on the problem [3-6; 14; 15], it is found that diagnosing competitiveness of an enterprise (within the system of complex assessment of an enterprise's development and formation of its prospects) includes evaluating its performance by corresponding components.

In this context, it is established that today there are significant disagreements among economists, lawyers, and practitioners regarding assessment of enterprise efficiency based on economic, statistical and legal information. In particular, the object of discussion is a complex of unresolved issues related to forming (constructing) and using a system of indicators for economic and statistical determination of enterprise efficiency with regard to legal information (legal aspects of doing business). All this has justified the relevance, appropriateness, and importance of conducting research in this direction and determined the object of the study - features of the formation, use and improvement of the system of indicators for economic and statistical determination of enterprise efficiency with regard to legal aspects of management.

Therefore, the aim of the study is to formulate theoretical principles and develop practical recommendations to improve the system of indicators for economic and statistical determination of enterprise efficiency (based on economic and mathematical modeling, with consideration for the specifics of practical solving of economic problems in managing economic systems and business processes) with regard to legal aspects of management.
To achieve the research goal - finding and justifying new solutions for managing enterprises in view of the studied problem, there used the following general scientific and special methods [16-18]:

1) the methods of systems analysis, data systematization, generalization and concretization, the graphical method, and the method of argumentation - to clarify the essence of the categories "enterprise performance efficiency", "enterprise costs" and "legal responsibility of a business";

2) theoretical and analytical methods, applied methods of economic and mathematical modeling with consideration for peculiarities of economic observations and measurements - to form (build) a system of indicators for economic and statistical determination of enterprise efficiency with regard to legal aspects of management.

Researches $[3 ; 8 ; 11 ; 19-21]$ conclude that efficiency of an enterprise - the ability of the enterprise to ensure the result (outcome) of the process, project, measures, etc., which is calculated as the ratio of the outcome (the result achieved in a certain form of expression - monetary, material, social, environmental, etc.) to the costs that provided this result in the system for determining result of economic activity "information - resource - time conditions (risk factor, opportunity) - responsibility".

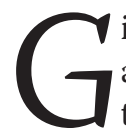
iven this, it is obvious that costs of an enterprise are 1) the monetary expression of the total enterprise's resources (financial, labor, material, energy, etc. [10]) used for particular purposes under certain conditions; 2 ) an indicator of performance efficiency of the enterprise, characterizing the amount of expenses (fixed, variable) incurred in the process of economic activity [11].

Based on studying operations [17], results of the analysis of systems for enterprise diagnosis [3; 12; 18;22], economic, managerial and legal aspects of management [5; 21;23-25], it can be pointed out that here special attention should be paid to problems of making managerial decisions (under constantly changing external influences) with regard to legal liability.

As concerns legal aspects of modern management, legal liability of a business should be understood as [5; $21 ; 23 ; 25]$

1) obligations of managers to observe the legality of their actions in achieving economic goals (taking into account the level of risk (Fig. 1), the time factor, and the relationship between the cost of additional information (economic, statistical, scientific, technical, sociological, legal, etc.) and profitability of its use). Here, profitability, as practice shows, should be considered as an composite financial indicator, reflecting the amount of income received, profit, production volume, sales volume, etc. $[5 ; 18]$;

2) five main groups of managers' legal obligations to owners (board of directors), staff (subordinates), customers, suppliers and competitors of the enterprise.

This legal aspect (regarding the legal responsibility of a business) is of extreme importance and priority in 


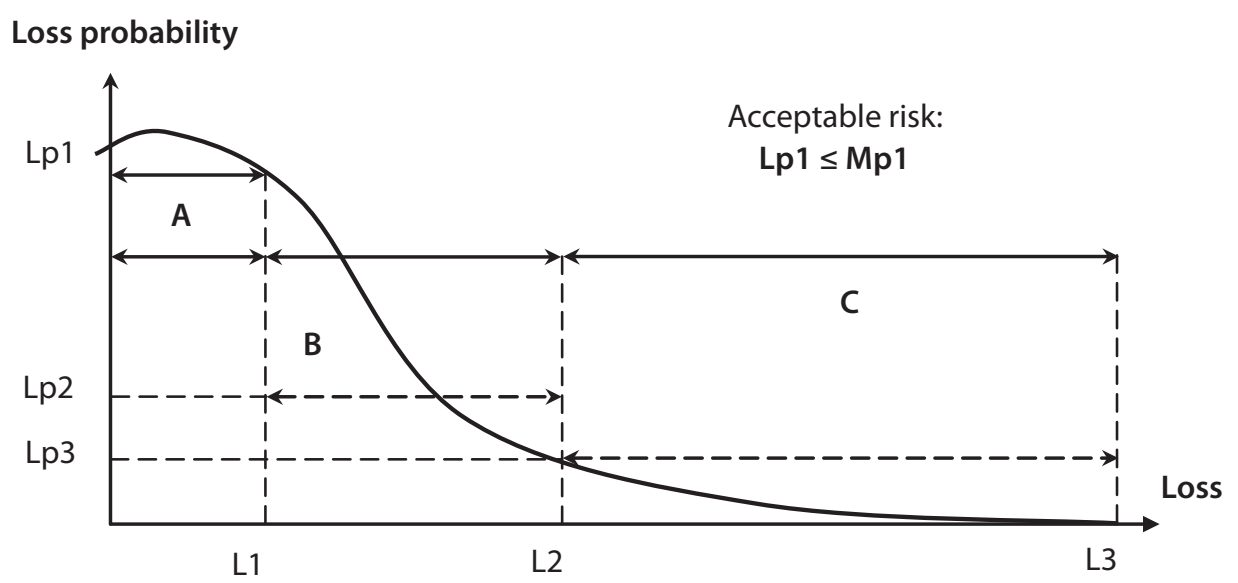
Symbols:
A - acceptable risk zone;
B - critical risk zone;
C - catastrophic risk zone;
Lp1 - allowable loss probability;
Lp2 - critical loss probability;
Lp3 - catastrophic loss probability;
L1 - allowable losses;
L2 - critical losses that are almost equivalent to the enterprise's property status;
L3 - losses that exceed the value of the enterprise's property;
Mp1 - marginal probability of acceptable risk

Fig. 1. Curve of distribution of enterprise's losses by risk zones

Source: developed by the author based on [25].

the VUCA world, especially given the circumstances that indicate the commission of administrative offenses in the financial sector [26-28].

$\mathrm{T}$ hus, given the formulation of the economic problem, its analysis and specific processes for constructing mathematical models (relevant, accurate, productive and economic) and their application to a real economic object under conditions and in the reality of the VUCA world [1;16-18], we recommend to present the improved system of indicators for the economic and statistical determination of enterprise efficiency (with regard to the legal aspects of management) in the form of economic and mathematical model $(1)$ [3; 5; 21;29-32]:

$$
\left\{\begin{array}{l}
I_{b} \geq I_{o} \geq I_{e} ; \\
T_{p}>T_{o}>T_{a}>100 \% \\
E_{E}=\frac{E_{R}}{C_{R}} ; \\
E_{E}=\langle F, P, C, L\rangle ; \\
F=\left\{f_{1}, f_{2}, f_{3}, f_{4}\right\} ; \\
P=\left\{p_{1}, p_{2}, p_{3}, p_{4}\right\} ; \\
C=\left\{c_{1}, c_{2}, c_{3}\right\} ; \\
L=\left\{l_{1}, l_{2}, l_{3}\right\} ;
\end{array}\right.
$$

where $I_{b}$ is business performance index (an increase in the enterprise's value as the result of the enterprise for the owners, creditors and other stakeholders); $I_{o}$ - owner performance index (increase in the enterprise's own capital as the result of the enterprise for the owner (owners)); $I_{e}-$ economic performance index (the enterprise's profit as the result of the enterprise for top managers); $T_{p}$ - profit growth rate; $T_{o}$ - sales growth rate; $T_{a}$ - asset growth rate; $E_{E}$ - enterprise efficiency; $E_{R}$ - outcome (result); $C_{R}$ costs (resources); $F$ - financial and economic efficiency; $P$ - production efficiency; $C$ - commercial efficiency; $L$ legal efficiency; $f_{1}$ - return on equity (assets); $f_{2}$ - overall liquidity ratio; $f_{3}$ - equity to total assets ratio; $f_{4}-$ financial leverage ratio; $p_{1}$ - capital-output ratio; $p_{2}$ - material productivity; $p_{3}-$ output capacity; $p_{4}$ - capital-labor ratio; $c_{1}$ - return on sales; $c_{2}$ - days payable outstanding; $c_{3}-$ days sales outstanding; $l_{1}$ - level of legality of managers' actions in achieving economic goals in the financial and economic sphere; $l_{2}$ - level of legality of managers' actions in achieving economic goals in the production sphere; $l_{3}-$ level of legality of managers' actions in achieving economic goals in the commercial sphere.

Taking into account the foregoing, it is advisable to note that in some cases, as business practice shows, the amount of profit (as the main summarizing indicator (result) of the enterprise's production and business activities for top managers) does not always adequately reflect the level of an enterprise's performance efficiency (outcome); cannot be the basis for making important managerial decisions. Therefore, the main task is not only to calculate 
the enterprise's efficiency (outcome) but also to perform a further in-depth analysis of other (additional) performance efficiency parameters, taking into account factors affecting the enterprise's management system and business processes. For example, we recommend, using correlation and regression analysis, to assess the influence of external factors and internal variables on the overall efficiency of an enterprise and identify reserves (internal, external) for its increase, especially under conditions of limited resources, information restrictions, etc.

The presented results should be taken into account when improving the system for comprehensive diagnosis of an enterprise's competitiveness in order to form (prepare, optimize) and support the process of making and implementing managerial decisions including checking the effectiveness of these decisions in the management system.

\section{CONCLUSIONS}

According to the results of the study, it is found that performance efficiency of an enterprise is the ability of the enterprise to ensure the result (outcome) of the process, project, activities, etc., which is calculated as the ratio of the outcome (the result achieved in a certain form of expression - monetary, material, social, environmental, etc.) to the costs that provided this result in the system for determining the result of economic activity "information - resource - time - conditions (risk factor, opportunity) - responsibility". As practice shows, for the economic and statistical determination of enterprise performance efficiency, problems related to making managerial decisions (that are constantly changing under external influences) with regard to legal liability are of importance. Here, the legal liability of a business should be understood as:

1) obligations of managers to observe the legality of actions in achieving the economic goals of the enterprise;

2) five main groups of managers' legal obligations to owners (board of directors), staff (subordinates), customers, suppliers, and competitors of the enterprise.

The scientific novelty of the study is in improving the system of indicators for economic and statistical determination of enterprise efficiency. The presented system, unlike the existing ones, reflects not only the integral level of financial, economic, industrial and commercial efficiency but also takes into account legal aspects of management, namely, legal efficiency, depending on the level of legality of managers' actions in achieving the economic goals of the enterprise in the financial, economic, industrial and commercial spheres.

\section{LITERATURE}

1. Popova N., Shynkarenko V., Kryvoruchko O., Zéman Z. Enterprise management in VUCA conditions. Economic Annals-XXI. 2018. № 170 (3-4). P. 27-31. DOI: https://doi.org/10.21003/ea.v170-05
2. Погорелов Ю. С. Моделювання розвитку підприємства. Актуальні проблеми економіки. 2009. № 10. C. 51-59. URL: http://base.dnsgb.com. ua/files/journal/Aktualni-problemy-ekonomiky/ Akt-prob-ekonomiky-2009-10/Akt-probekonomiky-2009-10_51-59.pdf

3. Мельник О. Г. Системи діагностики діяльності машинобудівних підприємств: полікритеріальна концепція та інструментарій : монографія. Львів : Видавництво «Львівської політехніки», 2010. 344 с.

4. Phusavat K., Haapasalo H., Lin B. Achieving enterprise competitiveness through an effective management process. Human Systems Management. 2011. Vol. 30. No. 3. P. $115-124$.

DOl: https://doi.org/10.3233/hsm-2011-0747

5. Кузьмін О. Є. Сучасний менеджмент. Львів : Центр Європи, 1995. 176 с.

6. Кузьмін О.Є., Мельник О. Г., Романко О.П. Конкурентоспроможність підприємства: планування та діагностика : монографія. Івано-Франківськ : ІФНТУНГ, 2011. 180 c.

7. Погорєлова Т. В. Статистичне визначення ефективності діяльності підприємств // Економіка підприємства: сучасні проблеми теорії та практики : матеріали Третьої міжн. наук.-практ. конф. (м. Одеса, 18-19 вересня 2014 р.). Одеса : Атлант, 2014. С. 128-129.

8. Отенко В. І. Формування аналітичного інструментарію оцінки ефективності діяльності підприємства. Бізнес Інформ. 2013. № 5. С. 232-237. URL: https:// www.business-inform.net/export_pdf/businessinform-2013-5_0-pages-232_237.pdf

9. Косянчук Т. Ф., Кучма С. В. Теоретичні засади оцінки ефективності діяльності підприємства за сучасних умов. Вісник Хмельницького начіонального університету. Серія «Економічні науки». 2014. № 3. T. 3. C. 113-116. URL: http://elar.khnu. km.ua/jspui/bitstream/123456789/3506/1/Vchnu_ ekon_2014_3\%283\%29_25.pdf

10. Скриньковський Р. М. Діагностика використання трудових, матеріальних, фінансових та енергетичних ресурсів підприємства як інструмент управління елементами його виробничо-господарської діяльності. Проблеми економіки. 2015. № 1. С. 249254. URL: https://www.problecon.com/export_pdf/ problems-of-economy-2015-1_0-pages-249_254.pdf

11. Загородній А. Г., Вознюк Г. Л. Фінансово-економічний словник. Львів : Видавництво Національного університету «Львівська політехніка», 2005. 714 с.

12. Павловські Г. Розвиток системи управлінської діагностики підприємства : автореф. дис. ... канд. екон. наук : 08.00.04. Львів, 2017. 20 с.

13. Серняк І. Формування та розвиток соціального інструментарію управління персоналом підприємства : автореф. дис. ... канд. екон. наук : 08.00.04. Львів, 2019. 20 c.

14. Mcdonald D., Smith A. A Proven Connection: Perforf mance Management and Business Results. Compensation \& Benefits Review. 1995. Vol. 27. Issue 1. P. 59-64. DOI: https://doi.org/10.1177/088636879502700111

15. Воронков Д. К., Погорелов Ю. С. Розвиток підприємства: управління змінами та інновації. Харків : АдвА, 2009. 435 c. 
16. Гайдучок В. М., Затхей Б. І., Лінник М. К. Теорія і технологія наукових досліджень : навч. посіб. Львів : Афіша, 2006. 232 c.

17. Карагодова О. О., Кігель В. Р., Рожок В. Д. Дослідження операцій : навч. посіб. Київ : ЦУЛ, 2007. 256 с.

18. Гетьман О. О., Шаповал В. М. Економічна діагностика : навч. посіб. Київ : ЦУЛ, 2007. 307 с.

19. Zulfakarova L. F., Kundakchyan R. M. Improving Assesss ment of Enterprise Economic Efficiency in the Current Market Conditions. Mediterranean Journal of Social Sciences. 2015. Vol. 6. Issue 1. S3. P. 274-276. DOI: https://doi.org/10.5901/mjss.2015.v6n1s3p274

20. Олексюк О. І. Результативність діяльності підприємств як основа формування їх інвестиційної привабливості. Інвестиції: практика та досвід. 2009. № 3. C. 21-26. URL: http://www.investplan.com.ua/ pdf/3_2009/8.pdf

21. Pellé S. Business, Innovation and Responsibility. Vol. 7. London : ISTE LTD, 2017. 182 p. DOI: https://doi.org/10.1002/9781119341079

22. Скриньковський Р. М., Крамар Р. І. Юридична діагностика підприємства. Порівняльно-аналітичне право. 2015. № 6. С. 230-233. URL: http://pap. in.ua/6_2015/70.pdf

23. Dale E. Management: Theory and Practice. 2nd ed. New York: McGraw-Hill Book Co, 1969. 786 p.

24. McFarland D. E. Management: principles and practices. $4^{\text {th }}$ ed. New York: Macmillan, 1974. $688 \mathrm{p}$.

25. Маркетинг та менеджмент: методи, моделі та інструменти : монографія / Лепа Р. М, Солоха Д. В., Коверга С. В. та ін. Донецьк : ТОВ «Східний видавничий дім», 2012. $250 \mathrm{C}$.

26. Заяць О. С. Протидія адміністративним правопорушенням у фінансовій сфері : монографія. Львів : ЛьвДУВС, 2018. 240 с.

27. Заяць О. С. Завдання та функції протидії правопорушенням у фінансовій сфері. Форум права. 2017. № 3. C. 53-58.

28. Заяць О. С. Форми адміністративно-правової протидії правопорушенням у фінансовій сфері. Право. ua. 2017. № 2. C. 42-46. URL: http://pravo.unescosocio.in.ua/wp-content/uploads/2019/12/Pravo_ ua_2017_2.pdf

29. Марченко О. І. Фінансові аспекти ділової активності підприємств. Фінанси України. 2007. № 5. С. 136-143.

30. Саленко О. В. Шляхи визначення ступеню ефективності діяльності підприємства. Економіка та управління підприємствами машинобудівної галузі: проблеми теорії та практики. 2013. № 4. С. 62-71.

31. Турило А. М., Зінченко О. А. Фінансово-економічні аспекти оцінки результатів і ефективності діяльності підприємства. Фінанси України. 2008. № 8 . C. 35-44.

32. Касич А. О., Хіміч І. Г. Методичні підходи щодо оцінки ефективності діяльності підприємства. Бізнес Інформ. 2012. № 12. С. 176-179. URL: https://www. business-inform.net/export_pdf/business-inform2012-12_0-pages-176_179.pdf

\section{REFERENCES}

Dale, E. Management: Theory and Practice. New York: McGraw-Hill Book Co, 1969.
Haiduchok, V. M., Zatkhei, B. I., and Linnyk, M. K. Teoriia i tekhnolohiia naukovykh doslidzhen [Theory and Technology of Scientific Research]. Lviv: Afisha, 2006.

Hetman, O. O., and Shapoval, V. M. Ekonomichna diahnostyka [Economic Diagnostics]. Kyiv: TsUL, 2007.

Karahodova, O. O., Kihel, V. R., and Rozhok, V. D. Doslidzhennia operatsii [Operations Research]. Kyiv: TsUL, 2007.

Kasych, A. O., and Khimich, I. H. "Metodychni pidkhody shchodo otsinky efektyvnosti diialnosti pidpryiemstva" [Methodological Approaches to Evaluating the Enterprise Activity Effectiveness]. Biznes Inform. 2012. https://www.business-inform.net/export_pdf/business-inform-2012-12_0-pages-176_179.pdf

Kosianchuk, T. F., and Kuchma, S. V. "Teoretychni zasady otsinky efektyvnosti diialnosti pidpryiemstva za suchasnykh umov" [Theoretical Foundations for Evaluating the Perfomance of the Enterprise for the Modern Condition]. Visnyk Khmelnytskoho natsionalnoho universytetu. Seriia «Ekonomichni nauky». 2014. http:// elar.khnu.km.ua/jspui/bitstream/123456789/3506/1/ Vchnu_ekon_2014_3\%283\%29_25.pdf

Kuzmin, O. Ye. Suchasnyi menedzhment [Modern Management]. Lviv: Tsentr Yevropy, 1995.

Kuzmin, O. Ye., Melnyk, O. H., and Romanko, O. P. Konkurentospromozhnist pidpryiemstva: planuvannia ta diahnostyka [Competitiveness of the Enterprise: Planning and Diagnostics]. Ivano-Frankivsk: IFNTUNH, 2011.

Lepa, R. M. et al. Marketynh ta menedzhment: metody, modeli ta instrumenty [Marketing and Management: Methods, Models and Tools]. Donetsk: TOV «Skhidnyi vydavnychyi dim», 2012.

Marchenko, O. I. "Finansovi aspekty dilovoi aktyvnosti pidpryiemstv" [Financial Aspects of Business Activity of Enterprises]. Finansy Ukrainy, no. 5 (2007): 136-143.

McDonald, D., and Smith, A. "A Proven Connection: Performance Management and Business Results". Compensation \& Benefits Review, vol. 27, no. 1 (1995): 59-64. DOI: https://doi.org/10.1177/088636879502700111

McFarland, D. E. Management: principles and practices. New York: Macmillan, 1974.

Melnyk, O. H. Systemy diahnostyky diialnosti mashynobudivnykh pidpryiemstv: polikryterialna kontseptsiia ta instrumentarii [Systems of Diagnostics of Activity of Machine-building Enterprises: Polycriteria Concept and Tools]. Lviv: Vydavnytstvo «Lvivskoi politekhniky», 2010.

Oleksiuk, O. I. "Rezultatyvnist diialnosti pidpryiemstv yak osnova formuvannia yikh investytsiinoi pryvablyvosti" [The Effectiveness of Enterprises as a Basis for the Formation of Their Investment Attractiveness]. Investytsii: praktyka ta dosvid. 2009. http://www.investplan.com. ua/pdf/3_2009/8.pdf

Otenko, V. I. "Formuvannia analitychnoho instrumentariiu otsinky efektyvnosti diialnosti pidpryiemstva" [Formation of Analytical Tools of Assessment of Company Effectiveness]. Biznes Inform. 2013. https://www. business-inform.net/export_pdf/business-inform2013-5_0-pages-232_237.pdf

Pavlovski, H. "Rozvytok systemy upravlinskoi diahnostyky pidpryiemstva" [Development of the System of Management Diagnostics of the Enterprise]: avtoref. dys.... kand. ekon. nauk:08.00.04, 2017. 
Pelle, S. Business, Innovation and Responsibility, vol. 7. London: ISTE LTD, 2017. DOI: https://doi.org/10.1002/9781119341079

Phusavat, K., Haapasalo, H., and Lin, B. "Achieving enterprise competitiveness through an effective management process". Human Systems Management, vol. 30, no. 3 (2011): 115-124. DOI: https://doi.org/10.3233/hsm-2011-0747

Pohorelov, Yu. S. "Modeliuvannia rozvytku pidpryiemstva" [Modeling of Enterprise Development]. Aktualni problemy ekonomiky. 2009. http://base.dnsgb. com.ua/files/journal/Aktualni-problemy-ekonomiky/ Akt-prob-ekonomiky-2009-10/Akt-prob-ekonomiky-2009-10_51-59.pdf

Pohorielova, T. V. "Statystychne vyznachennia efektyvnosti diialnosti pidpryiemstv" [Statistical Determination of the Efficiency of Enterprises]. Ekonomika pidpryiemstva: suchasni problemy teorii ta praktyky. Odesa: Atlant, 2014. 128-129.

Popova, N. et al. "Enterprise management in VUCA conditions". Economic Annals-XXI, no. 170 (3-4) (2018): 27-31. DOI: https://doi.org/10.21003/ea.v170-05

Salenko, O.V."Shliakhy vyznachennia stupeniu efektyvnosti diialnosti pidpryiemstva" [Ways of Determining the Efficiency of Enterprises]. Ekonomika ta upravlinnia pidpryiemstvamy mashynobudivnoi haluzi: problemy teorii ta praktyky, no. 4 (2013): 62-71.

Serniak, I. "Formuvannia ta rozvytok sotsialnoho instrumentariiu upravlinnia personalom pidpryiemstva“ [Formation and Development of Social Tools for Personnel Management of the Enterprise]: avtoref. dys. ... kand. ekon. nauk:08.00.04, 2019.

Skrynkovskyi, R. M.“'Diahnostyka vykorystannia trudovykh, materialnykh, finansovykh ta enerhetychnykh resursiv pidpryiemstva yak instrument upravlinnia elementamy yoho vyrobnycho-hospodarskoi diialnosti" [Diagnostics of Utilization of the Human, Material, Financial, and Energy Resources of the Enterprise as a Tool for Management of the Elements of Its Production and
Commercial Operations]. Problemy ekonomiky. 2015. https://www.problecon.com/export_pdf/problemsof-economy-2015-1_0-pages-249_254.pdf

Skrynkovskyi, R. M., and Kramar, R. I. "Yurydychna diahnostyka pidpryiemstva" [Legal Diagnostics of Enterprise]. Porivnialno-analitychne pravo. 2015. http:// pap.in.ua/6_2015/70.pdf

Turylo, A. M., and Zinchenko, O. A. "Finansovo-ekonomichni aspekty otsinky rezultativ i efektyvnosti diialnosti pidpryiemstva" [Financial and Economic Aspects of Evaluating the Results and Efficiency of the Enterprise]. Finansy Ukrainy, no. 8 (2008): 35-44.

Voronkov, D. K., and Pohorelov, Yu. S. Pozvytok pidpryiemstva: upravlinnia zminamy ta innovatsii [Enterprise Development: Change Management and Innovation]. Kharkiv: AdvA, 2009.

Zahorodnii, A. H., and Vozniuk, H. L. Finansovo-ekonomichnyi slovnyk [Financial and Economic Dictionary]. Lviv: Vydavnytstvo Natsionalnoho universytetu «Lvivska politekhnika», 2005.

Zaiats, O. S. "Formy administratyvno-pravovoi protydii pravoporushenniam u finansovii sferi" [Forms of Administrative and Legal Counteraction to Offenses in the Financial Sphere]. Pravo.ua. 2017. http://pravo. unesco-socio.in.ua/wp-content/uploads/2019/12/ Pravo_ua_2017_2.pdf

Zaiats, O. S. "Zavdannia ta funktsii protydii pravoporushenniam u finansovii sferi" [Tasks and Functions of Combating Offenses in the Financial Sector]. Forum prava, no. 3 (2017): 53-58.

Zaiats, O. S. Protydiia administratyvnym pravoporushenniam u finansovii sferi [Counteraction to Administrative Offenses in the Financial Sphere]. Lviv: LvDUVS, 2018.

Zulfakarova, L. F., and Kundakchyan, R. M. "Improving Assessment of Enterprise Economic Efficiency in the Current Market Conditions". Mediterranean Journal of Social Sciences, vol. 6, no. 1 (2015): 274-276. DOI: https://doi.org/10.5901/mjss.2015.v6n1s3p274 